IRA International Journal of Management \& Social Sciences

ISSN 2455-2267; Vol.08, Issue 02 (August 2017)

Pg. no. 188-199

Institute of Research Advances

http://research-advances.org/index.php/RAJMSS

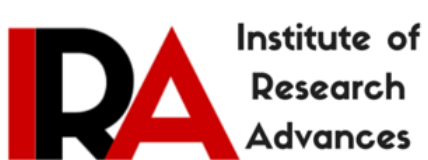

\title{
Teacher Performance: Evidence from Indonesia
}

\author{
Muhammad Abusama ${ }^{1}$, Murdifin Haming ${ }^{2}$, Baharuddin Latief ${ }^{3}$, Ariyati Arfah ${ }^{4}$ \\ ${ }^{1}$ Doctoral Student in the Faculty of Economics, Muslim University of Indonesia, Indonesia. \\ 2,3,4 Faculty of Economics, Muslim University of Indonesia, Indonesia.
}

Type of Review: Peer Reviewed.

DOI: http://dx.doi.org/10.21013/jmss.v8.n2.p6

\begin{abstract}
How to cite this paper:
Abusama, M., Haming, M., Latief, B., Arfah, A. (2017). Teacher Performance: Evidence from Indonesia. IRA-International Journal of Management \& Social Sciences (ISSN 2455-2267), 8(2), 188-199.
\end{abstract} doi:http://dx.doi.org/10.21013/jmss.v8.n2.p6

(C) Institute of Research Advances.

(cc) EY-NC

This work is licensed under a Creative Commons Attribution-Non Commercial 4.0 International License subject to proper citation to the publication source of the work.

Disclaimer: The scholarly papers as reviewed and published by the Institute of Research Advances (IRA) are the views and opinions of their respective authors and are not the views or opinions of the IRA. The IRA disclaims of any harm or loss caused due to the published content to any party.

Institute of Research Advances is an institutional publisher member of Publishers Inter Linking Association Inc. (PILA-CrossRef), USA. The institute is an institutional signatory to the Budapest Open Access Initiative, Hungary advocating the open access of scientific and scholarly knowledge. The Institute is a registered content provider under Open Access Initiative Protocol for Metadata Harvesting (OAI-PMH).

The journal is indexed \& included in WorldCat Discovery Service (USA), CrossRef Metadata Search (USA), WorldCat (USA), OCLC (USA), Open J-Gate (India), EZB (Germany) Scilit (Switzerland), Airiti (China), Bielefeld Academic Search Engine (BASE) of Bielefeld University, Germany, PKP Index of Simon Fraser University, Canada. 


\begin{abstract}
This study aims to examine and analyze empirically the effect of work motivation, competence and Islamic leadership on job satisfaction and teacher performance. The research was conducted on all teachers at vocational high school (SMK) in South Halmahera district with a sample of 154 teachers as respondents. Data from the questionnaires were analyzed by Structural Equation Models with the AMOS program Ver.20. The results of the study provide evidence of work motivation and no significant negative effect on job satisfaction. High teacher competences give real effect to increase job satisfaction. Islamic Leadership is either not able to provide a significant effect on job satisfaction. High motivation and demonstrated by teachers today significant effect on teachers performance. High competency has a positive influence but not real on teacher performance. Islamic Leadership is good and indicated by the head of school at this time have a positive and significant effect on teachers performance. The low of job satisfaction demonstrated has a negative and significant effect on teacher performance. The effect of Islamic leadership and work motivation through job satisfaction on performance teachers is positive but not significant. On the other hand the effect of competence through job satisfaction on teacher's performance has a negative and significant effect.
\end{abstract}

Keywords: Work motivation, competence, Islamic leadership, job satisfaction and teacher performance

\title{
Introduction
}

One of the main problems and very fundamental faced by Indonesia is the low quality of education at every level of the educational unit, especially primary and secondary education. Various attempts have been made to improve the quality of national education, among others through training and upgrading teacher qualifications, curriculum changes, procurement of books and teaching tools, repair other educational facilities and improving the quality of school management. Nevertheless, various indicators of the quality of education have not shown a significant increase. Some schools, especially in the cities show increasing the quality of education are considered quite encouraging, but more partially indeed is a very poor condition. Based on this information, either through the media as well as the facts on the ground, then the various parties questioning what went wrong in the implementation of our education and the observations and analysis, there are at least three factors that caused the quality of education has not increased evenly.

The first factor, policies and implementation of national education using the application of approach education production function is too focused on educational inputs and less attention to the educational process, but the process of education is critical educational output. The second factor is the implementation of the National Examination (UN) to be used as an instrument to improve the quality of education and including the Examination Schools, where they do not constitute integral unity. This suggests that in determining the criteria of graduation, there is a separation in the determination of the minimum criteria for the average graduation. Average national exam to measure cognitive (knowledge) and stand-alone and school examinations where there are subjects that make up the personality (character) who also stood with his group intact. The third factor is the role of the community, especially parents of students in education has been very minimal. Community participation has been generally more character input support fund, not on the educational process (decision-making, monitoring, evaluation, and accountability); the school does not have a duty to account for the results of the implementation of education to the community, especially parents, as one the main parties with an interest in education (stakeholders).

Ministry of Education in South Halmahera District (Indonesia) is an effort to improve the quality of human resources continues to explore ways and breakthrough among others by providing opportunities for all teachers to participate in education to a higher level, ranging from Graduate degree program, master and doctoral program. The Ministry of Education seeks to meet the needs of schools, such as; educational facilities in the form of building, mobile, equipment, textbooks, teaching aids and do not miss all the necessary comforts to trachea hold. Teacher force with the aim of educational services to run smoothly so that the creation of quality human resources. 


\section{Literature review}

\section{Work Motivation}

Along with perception, personality, attitudes, and learning, motivation is a very important part of understanding behavior. Luthan (1998) asserts that motivation should not be thought of as the only explanation of behavior, since it interacts with and acts in conjunction with other mediating processes and with the environment. Luthan stress that, like the other cognitive process, motivation cannot be seen. All that can be seen is behavior, and this should not be equated with causes of behavior. Luthan (1998) defines motivation as a process that starts with a physiological deficiency or need that activates a behavior or a drive that is aimed at a goal incentive". Therefore, the key to understanding the process of motivation lies in the meaning of, and relationship among, needs, drives, and incentives.

Relative to this, Robbins (2006) state that in a process that shows the individual intensity, direction, and persistence of effort toward achieving the goal. While the motivation in a general sense with regard to efforts to achieve objectives both individual and organizational goals empirical facts provide evidence that the Work motivation significant effect on job satisfaction of teachers (Brahmasari and Suprayetno, 2009; Singh and Sharma, 2016). Intrinsic and extrinsic motivation has a positive and significant effect on job satisfaction (Ahmed et al., 2010). The findings of the previous investigators obtain denials from other researchers, that motivation insignificant effect on job satisfaction (Dhermawan and Bagus. 2012). Causality among other variables provides evidence that, motivation positive and significant impact on the performance of lecturers (Tone et al. 2015). Inconsistency findings indicate that the work motivation insignificant effect on performance (Brahmasari and Suprayetno 2009; Dhermawan and Bagus, 2012; Hardjanto, D., 2017). Intrinsic and extrinsic motivation has a positive and significant effect on the performance of lecturers (Rimadias et al., 2017).

\section{Competence}

Competence is a crucial factor in whether someone is doing his job properly and correctly in accordance with standards established criteria. A. Competency is an underlying characteristic of an individual that is causally related to criterion referenced effective and or superior in a job or situation (Spencer and Spencer, 2008). The psychological presence at work consists in being attentive, focused, in being inside rather than outside the borders of a given role, in trying a sense of wholeness rather than fragmentation. This is what Reviews those who work experience when taking the deepest parts of themselves in the personal performance of the role and it is the condition for growth, learning, changing and productivity (Kahn and Byosiere, 1992).

According to Boyatzis (2008), competences in general are a set of capacities; abilities and qualities roommates have a positive influence on the performance of an organization. They can apply to technical, innovational and commercial capabilities, to the ability to be flexible and rapid, or in a wider sense, they are organizational capacities represent an organizational roommates observable behavior as related to the superior performances. There are three clusters of competencies differentiating outstanding from average performers in many countries of the World. Competence's significant effect on job satisfaction (Dhermawan and Bagus, 2012; Hardjanto, D., 2017). Competence is a positive and significant effect on employee performance (Danang Mukti Wibowo, 2014). Competence is not significant effect on the lecturers performance (Dhermawan and Bagus, 2012; Tone et al., 2015; Hardjanto, D., 2017).

\section{Islamic Leadership}

The leader must be a visionary leader to lead an organization into success (Ahmad Khaliq, 2009). The Qur'an is a continuing source of guidance, and the guidance it offers is in the context of what the reader is seeking. Learning from the Qur'an is a dynamic process and that is why we keep reading it in all sorts of circumstances and needs. Why look for lessons in leadership? Because all of us as Muslims and Muslimahs, must play a leadership role as enshrined by the almighty in one setting or another. Leadership in Islam is similar to conventional leadership except in its religious, moral, and human roots. Religious and moral spirit (fear of God) dominated leadership during the Prophet's Muhammad SAW and the Four Caliphs' reign (Al-Buraey, 2006).

From an Islamic perspective, the Islamic roots of leadership generally exist in the primary sources of the Shari'ah (Qur'an and Sunnah) in addition to the practices of the early Muslims. Complementarily, there is also a strand in conventional thought leadership that stresses the importance of spirituality, religious values, and human relationships. In essence, leadership is about offering oneself and one's spirit (Beekun and Badawi, 1999). The 
findings of previous studies proved that the leadership have a significant effect on job satisfaction (Brahmasari and Suprayetno 2009; Hardjanto, D., 2017). Proven research gaps on results showing that leadership style is not significant influence on employee satisfaction (Bakhri et al., 2015). Another fact, show that leadership, significant effect on individual performance (Brahmasari and Suprayetno 2009; Tone et al., 2015). The findings were obtained denials from other researchers that leadership is not significant effect on performance (Bakhri et al., 2015; Hardjanto, D., 2017).

\section{Job Satisfaction}

Spector (1997) described as job satisfaction simply how people feel about Reviews their jobs and different aspects of Reviews their jobs. According to Lawler (1990), job satisfaction Refers to people's feelings about the rewards they have received on the job. Job satisfaction is normally defined as an employee's affective reactions to a job based on a comparison of desired outcomes and actual outcomes (Cranny et al., 1992). Job satisfaction have a significant effect on performance (Brahmasari and Suprayetno 2009; Dhermawan and Bagus, 2012; Bakhri et al., 2015; Hardjanto, D., 2017). The different results, that job satisfaction is not significant effect on performance (Rimadias et al., 2017).

\section{Performance}

Employees Subjective form an overall perception of the organization based on such factors as degree of risk tolerance, team emphasis and support of people. This overall Becomes perception, in effect, the organization culture or personality. Reviews these favorable or unfavorable perception then Affect employee performance and satisfaction, with the impact being greater for stronger culture. (Robbins, 2001: 528).

Creation of high individual performance cannot be done directly; the results of previous studies provide evidence that intrinsic and extrinsic motivation indirectly significant influence on employee performance (Musleh, B. 2012). The higher the level of competence of the individual, the higher the performance it produces if it is supported by individual satisfaction in work (Chandra, FK, 2006). Job satisfaction proved as a partially mediator the effect of leadership on employee performance (Bakhri et al., 2015). There is a significant influence between leadership style to the individual performance mediated Job Satisfaction (Taruno et al., 2012).

\section{Material and Method}

Exploratory research used in this research are trying to find new relationships, and trying to explain the various symptoms caused by an object of research. 166 teachers Vocational High School (SMK) good status of Civil Servants (PNS) and contract employee (PTT) is used as a sample in this study. The construct of work motivation to develop measures used Robbins and Coulter (2004), which includes: The need for achievement, the need to have the authority or the authority, the need to work together or are affiliated, the need to gain an appreciation, the need to gain responsibility, and career development needs, as well as the need for promotion. Teacher Competence measurement used to develop Spencer and Spencer (2008), which include: pedagogic, personality, social competence and professional competence. Islamic Leadership measurement used to develop by Moeheriono (2013: 418), which includes: responsible (amanah), reliable (assiddiq), smart (fathonah), transparent (tabligh), conscious and cognizant (taqwa to Allah SWT), forgiveness (Ikhsan), to be fair (Al - Adl), voluntary (Ikhlas) and the deliberation (shura). Job satisfaction measurement used to develop Kreitner and Kinicki (2005); As'ad (2004: 115), which includes: Psychological factors, social, physical, and Financial Factors. Measurement of teachers performance develop the Directorate General of improving the quality of teachers and national education departments (2008), which includes: Quantity of learning outcomes, commitment to quality, use of media, target time, Standard Competence, Prime Services, and high integrity.

\section{Results}

\section{Relationship between work motivation and job satisfaction}

The effects of work motivation on job satisfaction can be evidenced by value the standardized regression weight estimate of -0.124 with a negative direction. The coefficient is negative, meaning that motivation is low, resulting in a decrease in teacher job satisfaction, but it can be evidenced also by the value of the critical ratio $(\mathrm{cr})=-0.718<$ 2.00 and a probability value of $0.473>=0.05$. The test results prove that the first hypothesis, work motivation has a negative and insignificant effect on job satisfaction. 
The statement can be interpreted that the motivation is low, not able to provide a significant effect (significant) towards the creation of teacher job satisfaction. This is because teachers do not receive support in establishing a harmonious relationship among teachers due to the geographical conditions of South Halmahera District is less support so that the process of drafting the curriculum and Learning Implementation Plan (RPP) cannot be implemented optimally, it can be seen from the low quality working relationships among teachers and working conditions that do not support teachers to implement the learning process with a good cause, and no significant negative effect on job satisfaction work motivation of teachers.

The cause of the negative and not significant effect between work motivation on teachers job satisfaction, in general due to demographic conditions are unfavorable where partially regency of South Halmahera include small islands making it difficult for teachers to carry out their duties coupled with the lack of support given from fellow teachers so that on several occasions the conflict. This condition is evidenced by the low quality of labor relations and working conditions that do not support that have an impact on the lack of interest, lack of peace work are perceived, and not worth the teacher's attitudes towards work and in some cases the profession as a teacher who becomes a life choice was not commensurate with the interests and talent then a low comfort in running his profession as a teacher.

The results support partially the two factor theory Frederick Herzberg proposed cited in DeShields et al. (2005) that if the working people a positive perception of the work, the satisfaction will be high. That is, if the level of individual satisfaction is high, then motivate an important aspect, whereas if there is no satisfaction, then hygiene factor. Supporting the empirical study, the work motivation is not significant effect on job satisfaction (Dhermawan and Bagus, 2012). The results of this study different from the findings Brahmasari and Suprayetno (2009); Ahmed Ishaq et al. (2010); Rimadias et al.(2017), the findings of previous researchers proved that the work motivation is a positive and significant effect on employee job satisfaction.

\section{Relationship between teacher competence and job satisfaction}

The effect of competence on job satisfaction can be demonstrated by the value standardized regression weight estimate of 0.650 with a positive direction. The coefficient is positive, meaning that the competence of teachers is high, resulting in an increase in job satisfaction vocational high school teacher in South Halmahera District, but it can be evidenced also by the value of the critical ratio $(\mathrm{cr})=3.987>2.00$ ) and a probability value of $0.000<0.05$. The test results prove that the second hypothesis, competence has a positive and significant effect on job satisfaction. The statement can be interpreted that the high competence of teachers and current teachers demonstrated by significant effect to increase of teachers job satisfaction, because the teacher has a high ability to communicate and interact effectively with the environment of the school and outside the school environment which leads to the establishment of social interactions both among teachers, with the leaders, and fellow teachers of different schools where they serve so that the condition the cause of a positive and significant effect on job satisfaction of teachers' competence.

The cause a positive and significant effect of competence on the teachers job satisfaction in outline is because teachers in performing their duties always act in an objective and non-discriminatory, teachers show empathy in communicating to fellow educators, parents and the community and teachers have a good attitude so enabling them to adapt to the environment of diverse cultural and social backgrounds are different as well as the teacher continues to build communication with other professions and other professions both oral and written, so the impact on the high sense of satisfaction that is felt by teachers today to build a harmonious relationship with the boss and relationships both with mates profession as well as their positive response from the employer to the achievement of the achievements obtained during this teacher to become a decisive factor in the creation of job satisfaction of teachers' work.

The results of this study support the theory put forward competence Spencer and Spencer (2008) Competence in addition to determining the behavior and performance of individuals also determine whether an individual to do his job properly and correctly in accordance with standards established criteria. The findings of this study support the study results by Dhermawan and Bagus (2012); Hardjanto, D. (2017) that the competence has a positive and significant effect on job satisfaction

\section{Relationship between Islamic leadership and job satisfaction}

The influence of Islamic leadership on job satisfaction can be evidenced by the value of standardized regression weight estimate of 0.190 with a positive direction. The coefficient is positive, meaning that the Islamic leadership is 
good, resulting in an increase in the high teachers job satisfaction vocational high school in South Halmahera District, but it can be evidenced also by the value of the critical ratio $(\mathrm{cr})=1.049<2.00$ and a probability value of $0.294>=0.05$. The test results prove that the third hypothesis, the Islamic leadership has a positive but not significant effect on teacher job satisfaction.

The statement can be interpreted that the Islamic leadership is good and indicated by the principal is not currently able to provide a significant effect to increase of teacher's job satisfaction. This is because in carrying out any work, the principal has the ability to always stay on the straight and always use the same size in the act are realized with equal treatment for teachers and the community around the school and make an assessment of the achievements of teachers with fair without looking at the background of the teacher was not yet able to increase the interest of teachers, tranquility work, attitude towards work and the welfare of teachers, which include payroll system, social security, the amount of allowances, facilities provided and the promotion of good which later became the cause positive but not significant effect of Islamic leadership on teachers job satisfaction. The cause is positive but not significant effect of Islamic leadership on teachers job satisfaction, in general due to the leadership must be fair to all teachers as well as the leadership of the assessment of the achievements of teachers but justice shown leadership has not been able to increase the interest and peace of the work and attitudes of teachers to work as evidenced by the discrepancy between the interests and talents with the option to work as teachers and lack of perceived convenience as teachers often insignificant influence of Islamic leadership on job satisfaction of teachers.

The results support partially proposed Islamic leadership, that Man as vicegerent of Allah on earth has the task of digging their leadership potential to provide care and devotion that is intended solely - the eye because of the mandate of God, that is by playing its role as a carrier of blessing for the universe (rahmatan lill alamin) (Quthb, 2001). Rasulullah SAW was sent by God to enhance human morals. Then partially support the Islamic leadership perspective, Islamic spiritual leadership is the ability to carry out orders and leave the ban Allah, well done jointly or individually, in other words, leadership is the ability to realize all the will of Allah that has notified him by the Prophet Mohammed, Leadership by empirical understanding of the activities carried out by humans in the life of a community in an effort to realize the togetherness (Nawawi, 1993). The results of this study support the findings of Bakhri et al. (2015) found leadership styles no significant impact on employee satisfaction. The study's findings differ from previous research Brahmasari and Suprayetno (2009); Hardjanto, D. (2017) that the leadership have a significant effect on job satisfaction.

\section{Relationship between work motivation and teacher performance}

The influence of work motivation on teacher performance can be demonstrated by value standardized regression weight estimate of -0.683 with a negative direction. The coefficient is negative, meaning that the low motivation of teachers work, resulting in a decline in the teachers performance of vocational high school in South Halmahera District, but it can be evidenced also by the value of the critical ratio (cr) $=-3.352<2.00$ and a probability value of $0.000<0.05$. The test results prove that the fourth hypothesis, work motivation has a negative and significant effect on the teacher's performance.

The statement can be interpreted that the high motivation and indicated by the teacher is currently providing significant effect to the improved performance of teachers. This is due to the high desire of teachers to obtain awards for his work so far and praise for the work that is inversely proportional to the low level of ability of teachers to the mastery of instructional materials and is represented on the ability of teachers of the method or process of preparing program of learning activities to develop syllabi and plans implementation of learning (RPP), which later became the cause of a negative and significant effect on the performance of teachers' work motivation.

The cause of the negative and significant effect of work motivation on teacher performance, in general due to the implementation of teachers have a strong desire to excel to the fullest, the achievements of teachers during this time due to the professionalism of teachers and achievement for teachers to get appreciation and schools to provide rewards the achievements obtained, these conditions have a significant impact on the willingness of teachers to improve the quality of learning implementation in order to educate students (learners) as well as consistency in the actions and values and issues generated and ultimately have an honest person and has a strong character as a reflection of a sense of satisfaction that is felt this during. Teacher's conditions are a cause of negative and significant effect of work motivation on perceived of teacher's job satisfaction. The results of this study support the theory put forward Herzberg motivation (cited in Lufthansa, 2006) that motivation is an impulse that drives a person to do activities as well as a boost in a person to do a job. Tiered support Maslow hierarchy of needs; cited in Luthans 
(2006) that man in principle have a number of needs that are classified in five levels or hierarchy of needs, namely: Physiological Needs; security; social; self-esteem; and self-actualization. This study supports the findings Tone $e t$ al. (2015), that work motivation is directly positive and significant impact on the performance of lecturers. The result of this study with the findings is different, work motivation no significant effect on performance (Dhermawan and Bagus, 2012; Hardjanto, D., 2017). Intrinsic and extrinsic factor have positive and significant effect on lecturer's performance (Rimadias et al., 2017). Work motivation has a positive but not significant effect on company performance (Brahmasari and Suprayetno, 2009)

\section{Relationship between competence and teacher performance}

Effect of competence on teacher performance can be demonstrated by value standardized regression weight estimate of 0.356 with a positive direction. The coefficient is positive, meaning that the competence of teachers is high, resulting in improved the high teacher performance at vocational high school in South Halmahera District, but it can be evidenced also by the value of the critical ratio $(\mathrm{cr})=1.698<2.00$ and a probability value of $0.090>0.05$. The fifth hypothesis testing results prove that, the competence is positive but not significant effect on teachers performance.

The statement can be interpreted that the high teacher competence and demonstrated by teachers today have a positive influence but not significant on teacher performance. This is because teachers have sufficient ability to communicate and interact effectively with the environment of the school and outside the school environment so as to improve the ability of teachers to conduct an evaluation of what has been achieved and done in a sustainable manner, but the effect is not obvious, the condition is a cause positive and no significant effect on the performance of teachers' competence. The cause is positive but not significant effect of competence on teacher performance, in general due to the teacher to do the job always act in an objective and non-discriminatory and continually communicate empathetically to fellow educators, parents and the community and able to adapt to the environment of diverse cultures and social background is different, then the teacher has the ability to establish communication, both orally and in but no real influence on the increase in the desire of teachers to strive to realize the quantity of learning outcomes specified in the RPP and the ability of teachers to provide a description of the knowledge, skills and attitude must be mastered students.

The results partially support of competence theory put forward by Antonacopoulou and Gerald (1996) mentions the competence consists of the unique properties of each individual are expressed in the process of interaction with others in a social context, so it is not just limited to the knowledge and skill-specific or performance standards expected and the behavior shown. So competencies include attitudes, perceptions and emotions and emphasis on personal interaction and social factors. Carrillo P. Robinson, et al. (2004: 46) that the competence can be demonstrated on two aspects; (1). Tacit knowledge is personal, developed through experience that it is difficult to be formulated and communicated by this means, it is categorized as a personal tacit knowledge or in other words the knowledge gained from the individual, and (2). Explicit knowledge formal and systematic easily communicated and shared. Application of explicit knowledge is easier because of the knowledge obtained in the form of writings or statements that are documented, so that every worker can learn independently. Supporting the findings that the positive effect was not significant competence on employee performance (Dhermawan and Bagus, 2012; Tone et al., 2015; Hardjanto, D., 2017). The results of this study differ from the findings, that the competence has a positive and significant effect on performance (Danang Mukti Wibowo, 2014).

\section{Relationship between Islamic leadership and teacher performance}

The effect of Islamic leadership on teacher performance can be demonstrated by value standardized regression weight estimate of 0.428 with a positive direction. The coefficient of influence is positive, meaning that the leadership of Islamic well and shown by the principal at this time, resulting in an increase in the high teachers performance at vocational high school in South Halmahera District, but it can be evidenced also by the value of the critical ratio $(\mathrm{cr})=2.120>2.00$ and a probability value of $0.034<0.05$. The sixth hypothesis testing results prove that, the Islamic leadership and significant positive impact on teacher performance.

The statement can be interpreted that the Islamic leadership is good and indicated by the head of the school is currently providing a positive and significant effect to increase the teachers performance. This is because the principal as the direct supervisor of teachers have the ability to be on the straight path and the actions and policies pursued by constantly using the same size in the face of the problems faced by teachers that have a significant impact on the ability of teachers to conduct an evaluation on what been achieved which is sustainable. Causes of 
positive and significant influence of Islamic leadership on teacher performance, the outline is because on several occasions principals as the direct supervisor of the teachers carry out their duties selflessly and always do the coaching, sharing knowledge with teachers without expecting anything in return and always prioritize the deliberation in the work plan, curriculum and lesson plans that then have a significant impact on the ability of teachers to always trying to convey to the students in the learning process of teaching materials within time specified and the creation of a high commitment of teachers in improving the quality of implementation of learning to educate students.

The results support the paradigm of leadership in Islam by Toto Tasmara (2002) consists of two parts: (a) Paradigm legally formalistic, the leadership exercised by the Muslims, the principles used are also of Islam, the symbols used are also reflect Islam. This is regardless of whether the way in the lead it holds to the fundamental principles of Islam or not, and (b) Paradigm essential substantial, the leadership of which there are values of Islam which is practiced in managing an organization, such as keeping the nature of the trust, honesty, justice, deliberation, sincerity, responsibility, and so forth. This is done regardless of whether the persons involved in it Muslims or nonMuslims. The findings of this study is in line with the concept of the caliphate, then humans are required to have the ability to explore and manage the world, both natural resources and human resources. Allah says in Sarah AlBanaras (2): 30 found Remember when you're Lord said to the angels: "I am going to make a vicegerent on earth." They say: 'Why do you want to make (caliph) therein one who will make mischief therein and shed blood, while we always exalt with the praise you and purify you? "Lord said: "Look, I know what you do not know. Partially findings supports Brahmasari and Suprayetno (2009); Tone et al. (2015) that the leadership of significant positive effect on performance. The study's findings differ from the results Bakhri et al. (2015); Hardjanto, D. (2017) found leadership no significant effect on employee performance.

\section{Relationship between job satisfaction and teacher performance}

Job satisfaction effect on teacher performance can be demonstrated by value standardized regression weight estimate of -0.315 with a negative direction. coefficient marked negative, meaning that the teacher job satisfaction is low, resulting in a decline in the teachers performance at vocational high school in South Halmahera District, but it can be evidenced also by the value of the critical ratio (cr) $=-2.114<2.00$ and value a probability of $0.035 \square 0.05$. The test results prove that the seventh hypothesis, that the Job satisfaction a negative and significant impact on teacher performance. The statement can be interpreted that the low job satisfaction of teachers and indicated by the teacher is currently providing a negative influence but distinct (significant) on teacher performance. This is due to the low interest of teachers in carrying out his profession as a teacher, tranquility work, attitude towards work and the payroll system is not adequate, social security, benefits, facilities are perceived less optimal but real impact on the creation of a teacher's ability to mastery of instructional materials and honesty teachers, teachers 'moral commitment and desire to do the right thing in the right way.

The cause of the negative and significant effect of job satisfaction on teachers performance, in general due to the low level of suitability held by teachers with an interest and talent contained within them, a feeling of discomfort in the work, and lack of satisfaction within themselves the educators, the low remuneration given to teachers, less than optimal health care services as perceived by teachers and poor leadership improvement efforts undertaken for their welfare as a teacher in practice proven to provide a significant impact on the high commitment of teachers in improving the quality of implementation of learning and ability of teachers to always trying to convey to the students teaching materials in accordance with the specified time target. The results support the ERG theory (existence, relatedness, and growth) of Alderfer cited in Gibson and Ivancevich (1992) that in carrying out one's life can do something needs coincided with the needs others as well. If the satisfaction of a need for a high level restrained, then the desire to meet the needs of the low will increase. The conclusion of the ERG theory, the need for low-level insatiable take someone to meet higher demand, but the dual needs to operate as a motivator as well. ERG theory is more consistent with current knowledge about individual differences such as education level, family background, environment and culture, tastes and others.

Then, this study supports the findings Hardjanto, D. (2017) that job satisfaction has a significant effect on employee performance. Brahmasari and Suprayetno (2009) employee satisfaction has a positive and significant effect on company performance. Bakhri et al. (2015) that job satisfaction is proven to improve employee performance. The results of this study different from the findings by Rimadias et al. (2017) that job satisfaction is positive but not significant effect on performance. 


\section{Effect of work motivation on teacher performance as a mediator job satisfaction}

The test results computing Sobel Test of mediator shows that the path coefficient values, the effect of work motivation on teachers performance as a mediator job satisfaction at 0,039 and probability value of $0.495>0.05$ so that based on these results can be explained that the effect of work motivation on teacher performance as a mediator job satisfaction is positive but not significant.

Factors causing the positive and not significant effect of work motivation on teacher performance as a mediator job satisfaction is the high teachers' work motivation shown by the high desire of teachers to further pursue personal achievement of the material benefits are realized with passion educating always better than the results previously achieved, but inversely with lower job satisfaction felt by teachers who are shown in the low the inability of teachers in working time arrangements and the lack of facilities supplies teachers' work as well as the low quality of care provided to teachers lead to low ability of teachers to be honest and have strong character in attitude and action, but it resulted in a decrease in the ability of teachers to provide a description of the knowledge, skills and attitude of the students to be the cause of positive and insignificant influence employee motivation through job satisfaction on the performance of teachers. Partially supporting the findings Musleh, B. (2012) that the extrinsic and intrinsic motivation indirectly significant influence on employee performance.

\section{Effect of competence on teacher performance as a mediator job satisfaction}

The test of results computing Sobel test of mediator, indicates that the value of the path coefficient effect of competence on teacher performance as a mediator job satisfaction of -0.205 and a probability value of $0.042<0.05$ so that based on these results can be explained that the effect of competence on teacher performance as a mediator job satisfaction is negative and significant.

Factors causing negative and significant effect of competence on teacher performance as a mediator job satisfaction due to teacher in carrying out its work always act in an objective and non-discriminatory and continually communicate empathetically to fellow educators, parents and the community and able to adapt to the environment of diverse cultural and social background is different, then the teacher has the ability to establish good communication orally and in but no real influence on the increase in the desire of teachers to strive to realize the quantity of learning outcomes specified in the RPP and the ability of teachers to provide a description of the knowledge, skills, and attitudes that must be mastered students then have an impact on the level of conformity held by teachers with an interest and talent contained within them, a feeling of discomfort in the work, and lack of satisfaction within themselves the educators, the low consideration given to teachers, less than optimal health insurance services can be felt early by teachers and poor leadership improvement efforts undertaken for their welfare as a teacher in practice proven to provide a significant impact on the high commitment of teachers in improving the quality of implementation of learning and ability of teachers to always trying to convey to the students teaching materials in accordance with the specified time target to trigger a negative and significant effect of competence through job satisfaction on the performance of teachers. The results of this study support the findings of Chandra, FK (2006) that based on the results of the path analysis found the influence of competence (professionalism) on the performance through job satisfaction, the higher the professional level, the higher the performance of individuals, especially if they are satisfied in their work

\section{Effect of Islamic leadership on teacher performance as a mediator job satisfaction}

The test results computing Sobel Test of mediator, indicates that the value of the path coefficient Islamic leadership on teacher performance as a mediator job satisfaction at 0.060 and probability value of $0.346>0.05$ so that based on these results can be explained that the influence of Islamic leadership through job satisfaction on teachers is positive but not significant.

Factors causing the positive and insignificant influence of Islamic leadership through job satisfaction on performance teacher due on several occasions principals as the direct supervisor of the teachers carry out their duties selflessly and always do the coaching, sharing knowledge with teachers without expecting anything in return and always prioritize the deliberation in the work plan, curriculum and lesson plans and the difference in interest and talent contained within the teacher with the choice of profession as a teacher, a feeling of discomfort in the work, and lack of satisfaction within themselves the educators and poor leadership improvement efforts undertaken for the welfare of teachers in the implementation proved unable to improve the integrity of teachers as educators. The results of this study supported research partially Bakhri et al. (2015). That job satisfaction in the research model is 
said to be partially mediator in explaining the effect of leadership style on employee performance. Then the study's findings differ from the results Taruno et al., (2012) that there is significant influence between Leadership Styles on the lecturer performance as a mediator Job Satisfaction

\section{Conclusions and recommendations}

The teachers does not support the harmonious relationships among teachers due to the geographical conditions of South Halmahera District is less support so that the process of drafting the curriculum and Learning Implementation Plan (RPP) cannot be implemented optimally, it's can be seen from the low quality working relationships among teachers and working conditions that do not support teachers to implement the learning process well. High teacher ability to communicate and interact effectively with the school environment and outside the school environment which leads to the establishment of good social interaction among teachers, with the leaders, and fellow teachers of different schools where they serve.

The school principal in carrying out any work, the principal has the ability to always be on the straight and always use the same size in the act are realized with equal treatment for teachers and the community around the school and make an assessment of the achievements of teachers with fair without looking at the background of teachers is not yet able to increase the interest of teachers, tranquility work, attitude towards work and the welfare of teachers, which include payroll system, social security, the amount of allowances, facilities provided as well as a good promotion. Desire high teacher to obtain awards for his work so far and praise for the work that is inversely proportional to the low level of ability of teachers to the mastery of instructional materials and is represented on the ability of teachers of the method or process of preparing program of learning activities to develop the syllabus and learning implementation plan (RPP).

The ability of sufficient teachers to communicate and interact effectively with the school environment and outside the school environment so as to improve the ability of teachers to conduct an evaluation of what has been achieved and done in a sustainable manner. The school principal as the direct supervisor, always teachers have the ability to be on the straight path and the actions and policies pursued by constantly using the same size in the face of the problems faced by teachers. The low interest of teachers in carrying his profession as a teacher, tranquility work, attitude towards work and the payroll system is not adequate, social security, benefits, facilities are perceived less optimal but real impact on the creation of a teacher's ability to mastery of instructional materials and honesty teacher, a moral commitment and the desire of teachers to do the right thing in the right way.

Work motivation high teacher indicated by the high desire of teachers to further pursue personal achievement of the material benefits are realized with passion educating always better than the results previously achieved, but inversely with lower job satisfaction felt by teachers who are shown with lower inability of teachers in making working time arrangements and the lack of facilities supplies teachers' work as well as the low quality of care provided to teachers lead to low ability of teachers to be honest and have strong character in attitude and action, but it resulted in a decrease in the ability of teachers to provide a description of the knowledge, skills and the attitude to the students to be the cause of positive and insignificant influence employee motivation through job satisfaction on the performance of teachers.

The factors causing negative and significant effect of competence on performance teachers as a mediator job satisfaction due to teacher in carrying out its work always act in an objective and non-discriminatory and continually communicate empathetically to fellow educators, parents and the community and able to adapt to the environment of diverse cultural and social background is different, then the teacher has the ability to establish good communication orally and in but no real influence on the increase in the desire of teachers to strive to realize the quantity of learning outcomes specified in the RPP and the ability of teachers to provide a description of the knowledge, skills, and attitudes that must be mastered students then have an impact on the level of conformity held by teachers with an interest and talent contained within them, a feeling of discomfort in the work, and lack of satisfaction within themselves the educators, the low consideration given to teachers, less than optimal health insurance perceived services early by teachers and poor leadership improvement efforts undertaken for their welfare as a teacher in practice proven to provide a significant impact on the high commitment of teachers in improving the quality of implementation of learning and ability of teachers to always trying to convey to the students teaching materials in accordance with the target specified time. 
The school principal as the direct supervisor of the teachers carry out their duties selflessly and always do the coaching, sharing knowledge with teachers without expecting anything in return and always prioritize the deliberation in the work plan, curriculum and lesson plans and the difference in interest and talent contained within the teacher with the choice of profession as a teacher, a feeling of discomfort in the work, and lack of satisfaction within themselves the educators and poor leadership improvement efforts undertaken for the welfare of teachers.

The necessary change in attitude, behavior and paradigm of the teacher, that in order to increase the motivation of teachers can be reached by making structured efforts (tiered) through; (1) enhancing support to the desire of teachers to be more intense in the pursuit of personal achievement compared with the urge to acquire rewards (material), (2) the creation of desire Teachers to have the authority they can use to influence fellow employees or educates students in the context of scientific, (3) teachers to always be involved in the work, (4) to obtain awards for his work so far and praise for the work, (5) teachers to be given a chance in structural positions in schools, and (6) the status of teachers on a career path that has been established, and (7) support to the desire of teachers to continue to gain support in conjunction with a fellow teacher who directs the creation of good behavior to make a harmonious relationship, and constantly strive avoid conflicts between fellow teacher needs to be a change in attitude, behavior and paradigm of the teacher, that to improve the competence of teachers, systematically can be reached by making structured efforts (tiered) through; (1) increase the ability of teachers to always act in an objective and nondiscriminatory, (2) increase the ability of teachers to have sufficient knowledge of the characteristics of learners, (3) The ability of teachers to always uphold the code of ethics of the teaching profession, and (4) the ability of teachers to continually strive to master the teaching materials corresponding RPP.

The necessary change in attitude, behavior and paradigm of the principal, that to create a good Islamic leadership systematically can be reached with a structured efforts (tiered) through; (1) the ability of the leadership to continue to conduct an assessment of the achievements of teachers with fair, (2) the ability of leaders to always do the coaching duties to teachers with a sincere, (3) the ability of the leadership to continuously deliver to the teachers against everything that is good or bad, (4) the ability of leaders to always prioritize the deliberation in preparing the RPP; (5) the ability of the leadership to continue to act and behave according to the laws that have been established by God Almighty, (6) the ability of the leadership to constantly strive to have a good memory to process and capturing the information, (7) the ability of leaders to always consider the various suggestions and complaints from teachers, (8) the ability of leaders to always have a strong belief that God sees what is done, and (9) the ability of the leadership to continuously create creative ideas.

The necessary change in attitude, behavior and paradigm from that to increase the job satisfaction of teachers is high, can be reached by systematically structured efforts (tiered) through; (1) improving the quality of relationships among teachers, (2) an increase in financial compensation and social security (BPJS) or the like, (3) an increase in conformity with the interests and talents, and (4) the provision of work equipment at the school in supporting job as a teacher. The necessary change in attitude, behavior and paradigm of the teacher, that in order to improve the performance of teachers is high, can be reached by systematically structured efforts (tiered) through; (1) increasing the commitment of teachers is high in improving the quality of implementation of learning, (2) acquisition of teaching materials in the learning process within time specified, (3) continue to work with oriented to service excellence, (4) empowering or using instructional media there efficiently, (5) attempt to realize the quantity prescribed learning outcomes in the lesson plan or curriculum, (6) improving the compatibility with the target achievement of competency standards that have been determined; and (7) improving the integrity of the work

\section{References}

[1] Ahmad, K. (2009). Leadership and work motivation from the cross cultural perspective. International journal of commerce and management, 19(1), 72-84.

[2] Ahmed, I., Nawaz, M. M., Iqbal, N., Ali, I., Shaukat, Z., \& Usman, A. (2010). Effects of motivational factors on employees job satisfaction a case study of University of the Punjab, Pakistan. International journal of business and management, 5(3), 70 .

[3] Al-Buraey, M.A. (2006), Islamic Principles in the Management of an Organization: A Focus on Leading, King Fahd University, Al-Dharan

[4] Antonacopoulou, E. P., \& Fitz Gerald, L. (1996). Reframing competency in management development. Human Resource Management Journal, 6(1), 27-48.

[5] As'ad, Mohamad. (2004). Psikologi Industri. Liberty: Yogyakarta 
[6] Bakhri, S., Modding, B., Gani, A., \& Lamo, M. (2015). Linking leadership style, work environment, job characteristics to civil servants performance: the mediating role of job satisfaction. International Journal of Humanities and Social Science Invention. 75-84

[7] Beekun, R. I., \& Badawi, J. A. (1999). Leadership: an Islamic perspective. Beltsville, MD: Amana.

[8] Boyatzis, R. E. (2008). Competencies in the 21st century. Journal of management development, 27(1), 5-12

[9] Brahmasari, IA, \& Suprayetno, A. (2009). Influence of Work Motivation, Leadership and Organizational Culture on Employee Satisfaction and Impact on Corporate Performance (Case Study at PT. Pei Hai International wiratama Indonesia). Journal of Management and Entrepreneurship, 10 (2), 124.

[10] Carrillo, P., Robinson, H., Al-Ghassani, A., \& Anumba, C. (2004). Knowledge management in UK construction: Strategies, resources and barriers. Project Management Journal, 35 (1), 46-56.

[11] Chandra, FK (2006). Supervision Measures Influence on the Performance of the Internal Auditor with work motivation as an intervening variable (Empirical Study at PT. Bank ABC) (Doctoral dissertation, Diponegoro University Graduate Program).

[12] Cranny, CJ, Smith, PC, \& Stone, EF (Eds.). (1992). Job satisfaction: How people feel about Reviews their jobs and how it Affects Reviews their performance. Lexington Books.

[13] Danang Mukti Wibowo, (2014), Effects of competence, motivation, organizational commitment to employee performance and job satisfaction of education. International Juotnal of Business and Management. Vol.5, 6; June 2014

[14] DeShields Jr., OW, Kara, A., \& Kaynak, E. (2005). Determinants of business student satisfaction and retention in higher education: applying Herzberg's two-factor theory. International journal of educational management, 19 (2), 128 139.

[15] Dhermawan, AANB, \& Bagus, N. (2012). Effect of Motivation, Work Environment, Competencies, and Job Satisfaction Compensation and Employee Performance in the Environment Office of the Public Works Department of Bali Province. Journal of Management, Business Strategy and Entrepreneurship, 6 (2), 173-184.

[16] Gibson, James L and Ivancevich, John. (1992). Organization and Management. Publisher. Erlangga, Jakarta.

[17] Hakim, BS (2007). Judge's work on traditional Islamic and Mediterranean Urbanism. International Journal of Architectural Research, 1 (2), 100-105.

[18] Hardjanto, D. (2017). The Influence Of Compensation, Leadership, Competence To Employee Performance Of RRI Surakarta With Motivation And Job Satisfaction As Intervening Variable. eAbstract Excellent, 3 (1).

[19] Kahn, RL, \& Byosiere, P. (1992). Stress in organisasi. In MD Dunnette \& LM Hough (Eds.), Handbook of industrial and organizational psychology (2nd ed., Vol. 3, pp. 571-650). Palo Alto, CA: Consulting Psychologists Press

[20] Kreitner, Robert. \& Angelo Kinicki. (2005). Organizational Behavior 2 (Issue 5). Salemba Empat, Jakarta

[21] Lawler III, EE (1990). Strategic Pay: Aligning organizational strategies and pay systems. Jossey-Bass.

[22] Luthans, Fred (2006). Organizational Behavior, Edisi Kesepuluh, Publisher Andy, Yogyakarta

[23] Luthans, Fred. (1998). Organization Behavior. International Edition, Sixth. Edition. Management, 8th edition. USA: John Wiley and Sons

[24] Moeheriono. (2013). Competency-Based Performance Measurement. Jakarta: PT. Raja Grafindo Persada

[25] Musleh, B. (2012). Analysis of the influence of motivation on job satisfaction and employee performance in PT Sang Hyang Seri (Persero) Regional III Malang. Journal of Management Application-Journal of Applied Management, 10 (4), 799-810.

[26] Nawawi, Hadari. (1993). Education in Islam. Surabaya: Al-Ikhlas

[27] Personnel Directorate of the Directorate General of Quality Improvement of Teachers and Education Personnel Ministry of Education. (2008). Teacher Performance. Jakarta

[28] Quṭb, S. (2001). In the Shade of the Qur'ān: Sūrahs 1-2. Al-Fātiḥah (Vol. 1). Islamic Foundation.

[29] Rimadias, S., Ferli, O., \& Hertingkir, F. (2017). The Role of Work Motivation and Job Satisfaction in Creating Employee Performance (Study on Permanent Lecturers of STIE Indonesia Banking School). Journal of Management Science and Economics, 9 (1), 24-47.

[30] Robbins, S. P (2006). Fundamentals of organizational behavior., New Jersey, United States. Pearson Prentice Hall. Upper Saddle River.

[31] Robbins, S. P., (2001). Organizational Behavior, 9th Ed. Upper Saddle River New Jersey 07458: Prentice Hall International

[32] Singh, SP, \& Sharma, HK (2016). Impact of Work Motivation on the Job Satisfaction of Teachers in Professional Education. The International Journal of Research Publication's. Research Journal of social science and management. Volume: 06 (05) .90-96

[33] Spector, PE (1997). Job satisfaction: Application, assessment, causes, and consequences (Vol. 3). Sage publications.

[34] Spencer, LM, \& Spencer, PSM (2008). Competence at Work models for superior performance. John Wiley \& Sons.

[35] Taruno, SC, Thoyib, A., Zain, D., \& Rahayu, M. (2012). engaruh Lecturer Performance Leadership Style on Job Satisfaction and Motivation at Work as Mediator (Studies in the College of Jayapura). Journal of Management Application-Journal of Applied Management, 10 (3), 495-509.

[36] Tone, K., Gani, MU, Nujum, S., \& Latif, B. (2015). The impact of the antecedent variables on lecturer'performance as mediated by work motivation. International Journal of Humanities and Social Science Invention. 4 (10) 54-62

[37] Toto, T. (2002). Cultivating Islamic Work Ethics. Jakarta Gema Insani. 